\title{
Crossing the line: migratory and homing behaviors of Atlantic bluefin tuna
}

\author{
Jay R. Rooker ${ }^{1, *}$, Haritz Arrizabalaga ${ }^{2}$, Igaratza Fraile ${ }^{2}$, David H. Secor ${ }^{3}$, \\ David L. Dettman ${ }^{4}$, Noureddine Abid ${ }^{5}$, Piero Addis ${ }^{6}$, Simeon Deguara ${ }^{7}$, F. Saadet \\ Karakulak $^{8}$, Ai Kimoto ${ }^{9}$, Osamu Sakai ${ }^{9}$, David Macías ${ }^{10}$, Miguel Neves Santos ${ }^{11}$ \\ ${ }^{1}$ Department of Marine Biology, Texas A\&M University, 1001 Texas Clipper Road, Galveston, Texas 77553 USA \\ ${ }^{2}$ AZTI Tecnalia, Marine Research Division, Herrea Kaia, Portualdea z/g 20110 Pasaia, Gipuzkoa, Spain \\ ${ }^{3}$ Chesapeake Biological Laboratory, University of Maryland Center for Environmental Science, PO Box 38, Solomons, \\ Maryland 20688, USA \\ ${ }^{4}$ Environmental Isotope Laboratory, Department of Geosciences, 1040 E. 4th Street, University of Arizona, Tucson, Arizona \\ 85721, USA \\ ${ }^{5}$ Institut National de la Recherche Halieutique, INRH, Regional Centre of Tangier, BP: 5268, Dradeb, Tangier, Morocco \\ ${ }^{6}$ Department of Life Science and Environment, University of Cagliari, Via Fiorelli 1, 09126 Cagliari, Italy \\ ${ }^{7}$ Federation of Maltese Aquaculture Producers 54, St. Christopher Str., Valletta VLT 1462, Malta \\ ${ }^{8}$ Faculty of Fisheries, Istanbul University, Ordu Cad. $\mathbf{N}^{\circ} 200,34470$ Laleli, Istanbul, Turkey \\ ${ }^{9}$ National Research Institute of Far Seas Fisheries, 5-7-1 Orido Shimizu, Shizuoka, Japan \\ ${ }^{10}$ Spanish Institute of Oceanography, Corazón de María 8, 28002 Madrid, Spain \\ ${ }^{11}$ Instituto Nacional dos Recursos Biológicos (INRB I.P. IPIMAR), Avenida 5 de Outubro s/n, 8700-305 Olhao, Portugal
}

\begin{abstract}
Assessment and management of Atlantic bluefin tuna Thunnus thynnus populations is hindered by our lack of knowledge regarding trans-Atlantic movement and connectivity of eastern and western populations. Here, we evaluated migratory and homing behaviors of bluefin tuna in several regions of the North Atlantic Ocean and Mediterranean Sea using chemical tags $\left(\delta^{13} \mathrm{C}\right.$ and $\delta^{18} \mathrm{O}$ ) in otoliths. Significant emigration of bluefin tuna from their place of origin was inferred from otolith $\delta^{13} \mathrm{C}$ and $\delta^{18} \mathrm{O}$, with both eastern and western bluefin tuna commonly 'crossing the line' $\left(45^{\circ} \mathrm{W}\right.$ management boundary) in the Central North Atlantic Ocean and mixing with the other population. Several western migrants were also detected in Moroccan traps off the coast of Africa, indicating that trans-Atlantic movement occurs for members of the western population; however, the degree of mixing declined with proximity to the eastern spawning area (Mediterranean Sea). The origin of bluefin tuna collected at the entrance to the Strait of Gibraltar and from several regions within the Mediterranean Sea (Balearic Islands, Malta, and Sardinia) was essentially $100 \%$ eastern fish, demonstrating that natal homing is well developed by the eastern population, with western migrants rarely entering the Mediterranean Sea.
\end{abstract}

KEY WORDS: Stable isotopes $\cdot$ Nursery origin $\cdot$ Otolith chemistry $\cdot$ Stock structure $\cdot$ Population connectivity $\cdot$ Migration $\cdot$ Philopatry

\section{Resale or republication not permitted without written consent of the publisher}

\section{INTRODUCTION}

The productivity and dynamics of marine fish populations are inherently influenced by patterns of movement during the life of an individual (Goethel et al. 2011). Species often require and use multiple habitats, ecosystems, or seas to complete their life cycle, and an improved understanding of movement and population connectivity is needed to effectively manage and rebuild harvested stocks. This is particularly true for highly migratory species (e.g. tunas), which are capable of traveling thousands of kilome- 
ters and often cross international jurisdictions or management boundaries during their lifetime (Block et al. 2005). Emigration and homing (leaving versus returning) are 2 types of dispersive behaviors that together represent critical life-history information for fisheries stock assessments. Movement related to both types of behavior can influence population estimates as well as the way stocks of highly migratory species are managed (Fromentin \& Powers 2005, Kerr et al. 2012). In response, emigration and homing rates are increasingly sought by intergovernmental regulatory organizations responsible for the conservation of highly migratory species.

The current management framework used by the International Commission for the Conservation of Atlantic Tunas (ICCAT) for stock assessments of bluefin tuna Thunnus thynnus assumes no connectivity of individuals between eastern (Mediterranean Sea) and western (Gulf of Mexico) production zones, despite the fact that trans-oceanic movement and population mixing is known to occur (Rooker et al. 2007). Movement of bluefin tuna across the $45^{\circ} \mathrm{W}$ management boundary has been observed with electronic tags (Block et al. 2005), highlighting the potential for consequential population mixing in certain regions of the North Atlantic Ocean (NAO). The impact of trans-Atlantic movement and mixing has been recently explored with simulation models, and findings clearly indicate that population estimates, fishing mortality, and long-term rebuilding expectations are strongly dependent on the movement and connectivity of eastern and western bluefin tuna populations (Taylor et al. 2011, Kerr et al. 2012).

Understanding the nature and magnitude of connectivity between eastern and western populations of bluefin tuna is essential to management efforts. It is, therefore, surprising that the stock composition of bluefin tuna in several regions of the NAO is presently unknown. Research using chemical tags in otoliths (ear stones) to predict the origin of bluefin tuna in the Northwest Atlantic Ocean (NWAO) indicated a large contribution of eastern-origin fish to USA waters, particularly for young bluefin tuna, with approximately $60 \%$ of the adolescents derived from spawning areas in the Mediterranean Sea (Rooker et al. 2008a). An investigation using organochlorine tracers in the muscle tissue of bluefin tuna also reported significant trans-Atlantic movement (east to west) and potentially high numbers of eastern origin fish in the NWAO (Dickhut et al. 2009). These findings underscore the need to characterize the stock structure of bluefin tuna in potential mixing zones throughout their range, including areas that are exploited by commercial fishing activities, such as the Central North Atlantic Ocean (CNAO), Northeast Atlantic Ocean (NEAO), and the Mediterranean Sea.

Trans-Atlantic movement by bluefin tuna may also influence the presence of strays in spawning areas, possibly leading to population-level effects (Secor 2002). Natal homing by bluefin tuna is presumed to occur with adults ostensibly exhibiting a high degree of philopatry to both the eastern and western spawning areas (>95\%) (Rooker et al. 2008a). Nevertheless, fidelity to spawning areas has been questioned (Galuardi et al. 2010), and a more comprehensive assessment of homing behavior is warranted given the limited nature and scope of previous investigations. This is particularly true for the Mediterranean Sea because discrete spawning areas are known to exist in different regions of this basin (MacKenzie \& Mariani 2012). It is possible that areas near the entrance (Strait of Gibraltar) or in close geographic proximity to the Atlantic Ocean may receive higher numbers of western strays relative to other areas that are far removed from the entrance, including parts of the eastern Mediterranean Sea (i.e. Levantine Sea), which may serve as a spawning area for a resident population of bluefin tuna (De Metrio et al. 2005).

The aim of the present study was to evaluate migratory and homing behaviors of bluefin tuna in the NAO and Mediterranean Sea using chemical tags $\left(\delta^{13} \mathrm{C}\right.$ and $\left.\delta^{18} \mathrm{O}\right)$ in otoliths. Prior research has demonstrated that stable isotopes, particularly otolith $\delta^{18} \mathrm{O}$, are valuable for discriminating bluefin tuna from putative nurseries (Rooker et al. 2006, 2008a). Otolith $\delta^{18} \mathrm{O}$ of bluefin tuna from the cooler and more saline waters in the eastern Atlantic Ocean and Mediterranean Sea is significantly enriched relative to individuals from the US Atlantic Ocean (western population), and observed spatial variation in $\delta^{18} \mathrm{O}$ is consistent with global patterns in the oxygen isotopic ratio of seawater (LeGrande \& Schmidt 2006). Local climatic conditions have been shown to affect seawater $\delta^{13} \mathrm{C}$ and/or $\delta^{18} \mathrm{O}$ in regions inhabited by bluefin tuna (Pierre 1999), leading to temporal variability in the chemical composition of bluefin tuna from eastern and western nurseries (e.g. Rooker et al. 2006, 2008a); however, the difference between nurseries is greater than interannual variability within each nursery, indicating these natural markers are relatively stable temporally (Rooker et al. 2008b, Schloesser et al. 2010). This study builds on prior research that first documented pronounced population mixing of eastern and western bluefin tuna in the NWAO (Rooker et al. 2008a,b), and our intention here was to comprehensively assess straying and homing behaviors of 
bluefin tuna from several regions within their range. Specifically, we investigated the nursery origin of bluefin tuna from the CNAO, both east and west of $45^{\circ} \mathrm{W}$ (management boundary), as well as areas of the NEAO near the entrance (Strait of Gibraltar) to the Mediterranean Sea. In addition, the nursery origin of bluefin tuna from several regional seas (Balearic Sea, Tyrrhenian Sea, Ionian Sea, and Levantine Sea) within the Mediterranean spawning area was determined.

\section{MATERIALS AND METHODS}

Yearling bluefin tuna Thunnus thynnus (ca. 12 to 18 mo old) from eastern and western nurseries were collected from 1998 to 2011 from the Mediterranean Sea/Bay of Biscay and the Gulf of Mexico/USA Atlantic Ocean, respectively. Eastern (Mediterranean Sea) and western (Gulf of Mexico) nursery designations included areas proximal to each (east = Bay of Biscay, west = USA Atlantic) because bluefin tuna commonly move from spawning and/or nursery areas to these locations during the first year of life (Rooker et al. 2007). To develop a comprehensive baseline, we targeted yearling bluefin tuna from multiple locations in the east (Bay of Biscay, Balearic Sea, Ionian Sea, Ligurian Sea, Tyrrhenian Sea) and west (USA Atlantic from Virginia to Massachusetts) from 1998 to 2011 (hereafter referred to as eastern or western nurseries). Samples were collected in both eastern and western nurseries for the majority of years in our baseline period (east: 9 year classes, west: 7 year classes). Sampling strategies used to collect yearling bluefin tuna included hook and line, lighted purse seines, longlines, and baitboats. Younger (age-0) specimens are often desired for documenting nursery origin because east to west movement may occur for age-1 to age-2 bluefin tuna (Rodríguez-Marín et al. 2005). Unfortunately, age-0 bluefin tuna are not readily available from the western nursery, preventing the development of a representative age-0 baseline.

Bluefin tuna in the medium (25 to $100 \mathrm{~kg}$ ) and large $(>100 \mathrm{~kg}$ ) size categories were used here to assess straying and homing behaviors of bluefin tuna collected from locations in the CNAO, NEAO, and Mediterranean Sea (Fig. 1) under an international biological sampling program funded by ICCAT. Our assessment of medium and large category bluefin tuna focused primarily on specimens near or over $100 \mathrm{~kg}$ in weight. All medium and large category bluefin tuna are referred to hereafter as 'adults' to simplify the presentation. Due to considerable differences in age-at-maturity between eastern and western bluefin tuna populations (Fromentin \& Powers 2005), we acknowledge that some individuals in our sample were likely juveniles. Adult bluefin tuna were collected from several areas of the CNAO, NEAO, and Mediterranean Sea in 2010 to 2012 under the provision of the ICCAT Atlantic Wide Research Program for Bluefin Tuna (GBYP). Specimens were obtained both east and west of the $45^{\circ} \mathrm{W}$ management boundary in the CNAO and also from trap fisheries in the NEAO (Morocco, Portugal, and Spain) located near the entrance (Strait of Gibraltar) to the Mediterranean Sea. Within the Mediterranean Sea spawning area, adult bluefin tuna were collected from 4 regional seas: Balearic Sea (Spain), Tyrrhenian Sea (Sardinia), Ionian Sea (Malta), and Levantine Sea (Cyprus).

A single sagittal otolith (left or right) for each bluefin tuna was selected, cleaned, and rinsed following a well-established protocol (Rooker et al. 2008b). Otoliths of yearling and adult bluefin tuna were then embedded in Struers epoxy resin (Struers A/S). Next, a $1.5 \mathrm{~mm}$ thick section was cut along a transverse plane using a Buehler IsoMet saw. Thin sections were then attached to a sample plate using Crystalbond thermoplastic glue (SPI Supplies/Structure Probe), and the region corresponding to the first year of growth was isolated and powdered using a New Wave Research Micro-Mill and a standard milling template designed for yearling bluefin tuna following Rooker et al. (2008b). A series of drill passes was run over a preprogrammed drill path using a $500 \mu \mathrm{m}$ diameter Brasseler carbide bit (Brasseler USA) until a depth of $800 \mu \mathrm{m}$ was reached. For a yearling bluefin tuna, this represents a small fraction $(\sim 9 \%)$ of the distance between the rostrum to anti-rostrum. Approximately $1.0 \mathrm{mg}$ of powder was collected during the milling of each otolith, and a fraction of the powder was loaded into sample trays for stable isotope analysis.

Otolith $\delta^{13} \mathrm{C}$ and $\delta^{18} \mathrm{O}$ was determined using an automated carbonate preparation device (KIEL-III; Thermo Fisher Scientific.) coupled to a gas chromatograph-isotope ratio mass spectrometer (Finnigan MAT 252; Thermo Fisher Scientific) at the University of Arizona. Powdered otolith samples (ca. 40-80 $\mu \mathrm{g}$ ) were reacted with dehydrated phosphoric acid under vacuum at $70^{\circ} \mathrm{C}$. The isotope ratio measurement was calibrated based on repeated measurements of National Bureau of Standards (NBS) NBS-19 and NBS-18, with 6 standards run for every 40 samples; precision was $\pm 0.08 \%$ o (SD) and $\pm 0.11 \%$ o (SD) for 

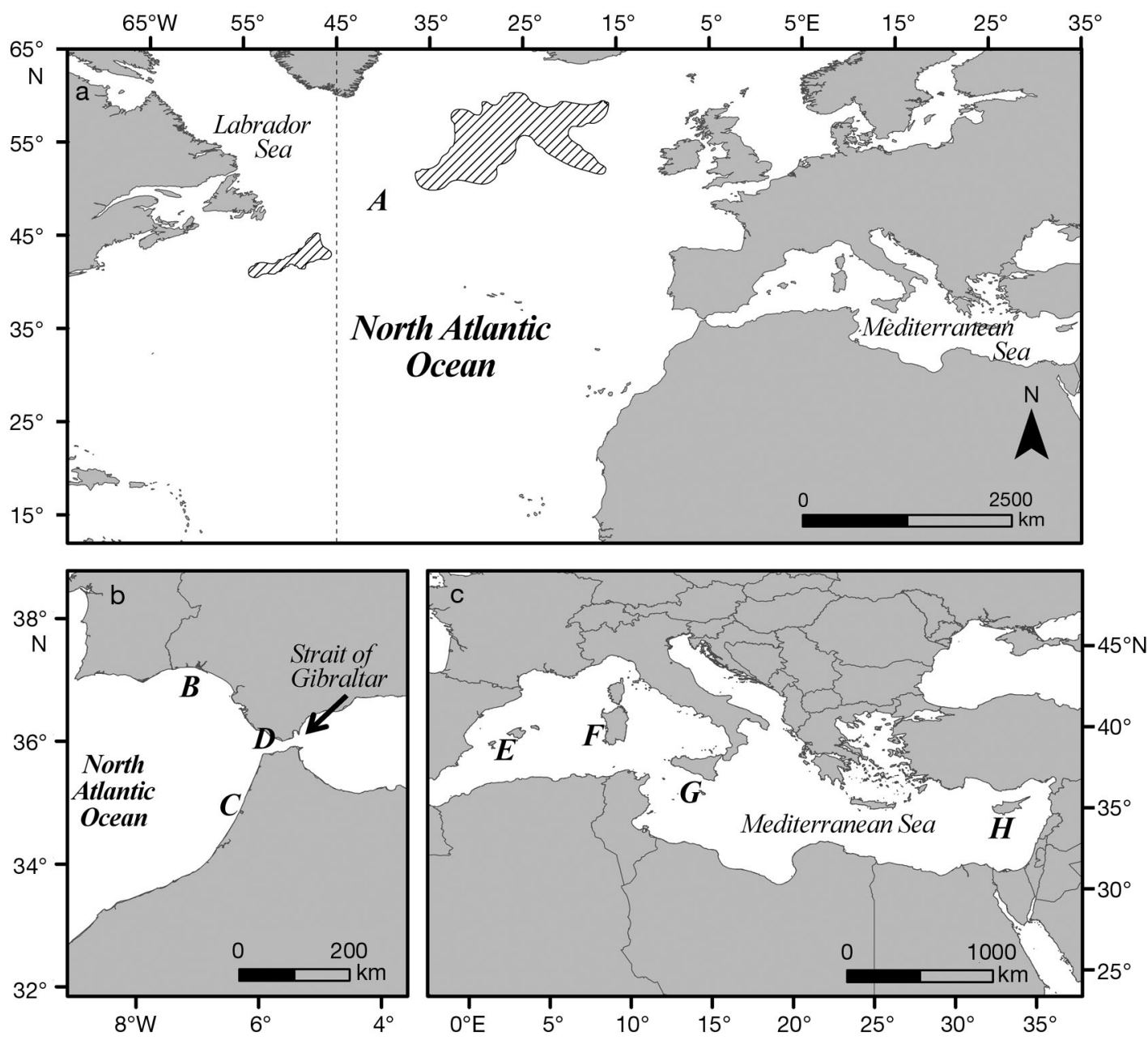

Fig. 1. Collection sites for bluefin tuna Thunnus thynnus: (a) Central North Atlantic Ocean (CNAO; A), (b) Northeast Atlantic Ocean (B: Portugal, C: Morocco), Strait of Gibraltar (D: Spain), and (c) Mediterranean Sea (E: Balearic Islands, F: Sardinia, G: Malta, $H$ : Cyprus). In (a) areas with striped lines east and west of the $45^{\circ} \mathrm{W}$ longitude or management boundary (dashed line) denote the areas sampled in the CNAO

$\delta^{13} \mathrm{C}$ and $\delta^{18} \mathrm{O}$, respectively. Otolith $\delta^{13} \mathrm{C}$ and $\delta^{18} \mathrm{O}$ values are reported relative to the Vienna Pee Dee Belemnite (VPDB) scale after comparison to an inhouse laboratory standard calibrated to VPDB.

Multivariate analysis of variance (MANOVA) was used to test for differences in otolith $\delta^{13} \mathrm{C}$ and $\delta^{18} \mathrm{O}$ values of yearling bluefin tuna from eastern and western nurseries, and significance was based on Pillai's trace statistic. Univariate tests were also performed individually for otolith $\delta^{13} \mathrm{C}$ and $\delta^{18} \mathrm{O}$ values using an analysis of variance (ANOVA). Quadratic discriminant function analysis (QDFA) was used to evaluate the classification accuracy of yearlings to eastern and western nurseries because this analysis does not have the homogeneity of covariance matrices assumption and is robust to moderate deviations from normality (McGarigal et al. 2000).
Region-specific estimates of nursery origin were determined by comparing $\delta^{13} \mathrm{C}$ and $\delta^{18} \mathrm{O}$ values in the otolith cores of adult bluefin tuna (corresponds to otolith material deposited during the yearling period) to $\delta^{13} \mathrm{C}$ and $\delta^{18} \mathrm{O}$ values from otoliths of yearlings (i.e. baseline sample). Mixed-stock predictions were generated using a baseline that included samples collected over the $14 \mathrm{yr}$ period and from multiple locations within both eastern and western nurseries (See Table S1 in the Supplement; www.int-res.com/ articles/suppl/m504p265_supp.xls). This approach relies on the assumption that otolith $\delta^{13} \mathrm{C}$ and $\delta^{18} \mathrm{O}$ for our baseline sample of yearling bluefin tuna is distinct between eastern and western nurseries even when multiple collection years or locations within a nursery are included. Previous research investigating otolith $\delta^{13} \mathrm{C}$ and $\delta^{18} \mathrm{O}$ of yearling bluefin tuna has 
shown that spatial variability (within a nursery) and temporal variability (across year classes) are insignificant for the primary marker used for stock discrimination (i.e. $\delta^{18} \mathrm{O}$ ) (Rooker et al. 2008b). As a result, our extended baseline will not degrade stock discrimination or bias estimates of nursery origin because differences between eastern and western nurseries were retained even when samples were drawn from different years or locations within a nursery. Furthermore, overall cross-validated classification success (QDFA) of yearlings to eastern and western nurseries using the 1998-2011 baseline sample was comparable to that reported by Rooker et al. (2008a). Both lines of evidence support the use of a pooled baseline (years) for predicting the nursery origin of adult bluefin tuna. Interdecadal variation in otolith $\delta^{13} \mathrm{C}$ and $\delta^{18} \mathrm{O}$ values has been reported for bluefin tuna $\left(\delta^{13} \mathrm{C}: 0.026 \mathrm{yr}^{-1}, \delta^{18} \mathrm{O}: 0.004 \mathrm{yr}^{-1}\right.$; Schloesser et al. 2009), suggesting that longer-term changes in otolith $\delta^{13} \mathrm{C}$ and $\delta^{18} \mathrm{O}$ also have the potential to influence our predictions. Because our baseline included yearlings collected over an extended period of time, QDFA analysis was performed on the 1998-2011 baseline sample with and without adjustments to account for temporal changes in otolith $\delta^{13} \mathrm{C}$ and $\delta^{18} \mathrm{O}$. Total cross-validated classification success to eastern and western nursery areas was identical between the 2 forms of the 1998-2011 baseline sample, and thus, no adjustments were made prior to mixed-stock analysis.

The nursery origin (eastern versus western) of adult bluefin tuna from different regions of the Atlantic Ocean and Mediterranean Sea was predicted using direct maximum likelihood estimation (MLE) and classification-based estimation (maximum classification likelihood, MCL) from the mixed-stock analysis program HISEA (Millar 1990). We focus on conditional MLE because the performance is typically superior to classification-based methods; however, classification-based methods such as MCL appear to be more robust than direct MLE to anomalies in baseline data, and thus, results from this estimator are included for comparative purposes (Millar 1987, 1990). HISEA was run under bootstrap mode to obtain standard deviations around estimated proportions (error terms) with 500 simulations. Prior to mixed-stock analysis, otolith $\delta^{13} \mathrm{C}$ and $\delta^{18} \mathrm{O}$ values of yearling (baseline) and adult bluefin tuna were plotted in ordination space to further evaluate whether all potential source populations (i.e. nurseries) were sampled. A small percentage of otolith $\delta^{13} \mathrm{C}$ and $\delta^{18} \mathrm{O}$ values from our sample of adult bluefin tuna occurred outside 99\% confidence ellipses (Fang
2004) of the yearling baseline, ranging from $0 \%$ in most regions to a high of $2 \%$ for the sample from the Strait of Gibraltar. Given that otolith $\delta^{13} \mathrm{C}$ and $\delta^{18} \mathrm{O}$ values for adult bluefin tuna of unknown origin were almost entirely within the confidence ellipses of our yearling samples, potential bias due to the presence of individuals from other nurseries not sampled was assumed to be zero (Chittaro et al. 2009).

\section{RESULTS}

Otolith $\delta^{13} \mathrm{C}$ and $\delta^{18} \mathrm{O}$ values of yearling bluefin tuna Thunnus thynnus collected from 1998 to 2011 in eastern $(n=150)$ and western $(n=115)$ nurseries were distinct (MANOVA, $\mathrm{p}<0.001$, Fig. 2). Otolith $\delta^{13} \mathrm{C}$ values of yearlings in our baseline sample differed for individuals collected in eastern (mean \pm $\mathrm{SD}=-8.61 \pm 0.47 \%$ ) and western (mean $\pm \mathrm{SD}=$ $-8.74 \pm 0.50 \%$ ) nurseries (ANOVA, $\mathrm{p}<0.05$ ), although the difference was $<0.2 \%$. In contrast, the difference in otolith $\delta^{18} \mathrm{O}$ values of yearlings from eastern and western nurseries was more pronounced, with bluefin tuna of eastern origin having higher (enriched in heavier isotope) values (mean \pm $\mathrm{SD}=-0.81 \pm 0.19 \%$ ) relative to yearlings collected in the west $(-1.29 \pm 0.33 \%$ ) (ANOVA, $\mathrm{p}<0.001)$. QDFA parameterized with otolith $\delta^{13} \mathrm{C}$ and $\delta^{18} \mathrm{O}$ values from all year classes indicated that cross-validated classifi-

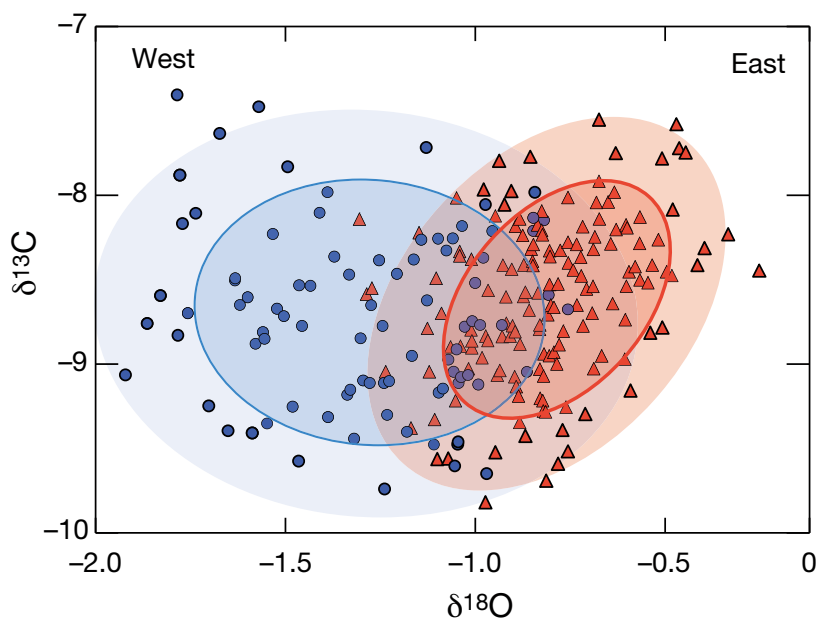

Fig. 2. Otolith $\delta^{13} \mathrm{C}$ and $\delta^{18} \mathrm{O}$ (Vienna PeeDee Belemnite, VPDB) values for yearling bluefin tuna used as the baseline sample. Samples are for bluefin tuna collected in eastern (red triangles, Mediterranean Sea/Bay of Biscay, $\mathrm{n}=150$ ) and western (blue circles, Gulf of Mexico/US Atlantic Ocean, n = 115) nurseries. All values are based on milled otolith core material from $1.5 \mathrm{~mm}$ thin sections. Confidence ellipses provided for eastern and western baseline samples; inner ellipse with solid line represents $1 \mathrm{SD}$ (68\% of sample); outer ellipse with lighter shading represents $2 \mathrm{SD}$ ( $95 \%$ of sample) 
cation success of yearlings to eastern and western nurseries was 90 and $73 \%$, respectively (overall $83 \%)$. Although both otolith $\delta^{13} \mathrm{C}$ and $\delta^{18} \mathrm{O}$ values varied significantly between nurseries investigated, our ability to discriminate yearling bluefin tuna from eastern and western nurseries was due almost entirely to otolith $\delta^{18} \mathrm{O}$. Classification success from QDFA based on this marker alone $(90 \%$ east and $71 \%$ west) was nearly comparable to the full model. Nevertheless, both otolith $\delta^{13} \mathrm{C}$ and $\delta^{18} \mathrm{O}$ values were used in our baseline data for mixed-stock runs to predict the origin of bluefin tuna from possible mixed-stock fisheries in the Atlantic Ocean and Mediterranean Sea.

Otolith $\delta^{13} \mathrm{C}$ and $\delta^{18} \mathrm{O}$ values from milled cores (corresponding to the yearling period) collected in the CNAO were used to assess the origin of adult bluefin tuna. Direct or predicted age estimates (Table 1) were used to determine birth year of adult bluefin
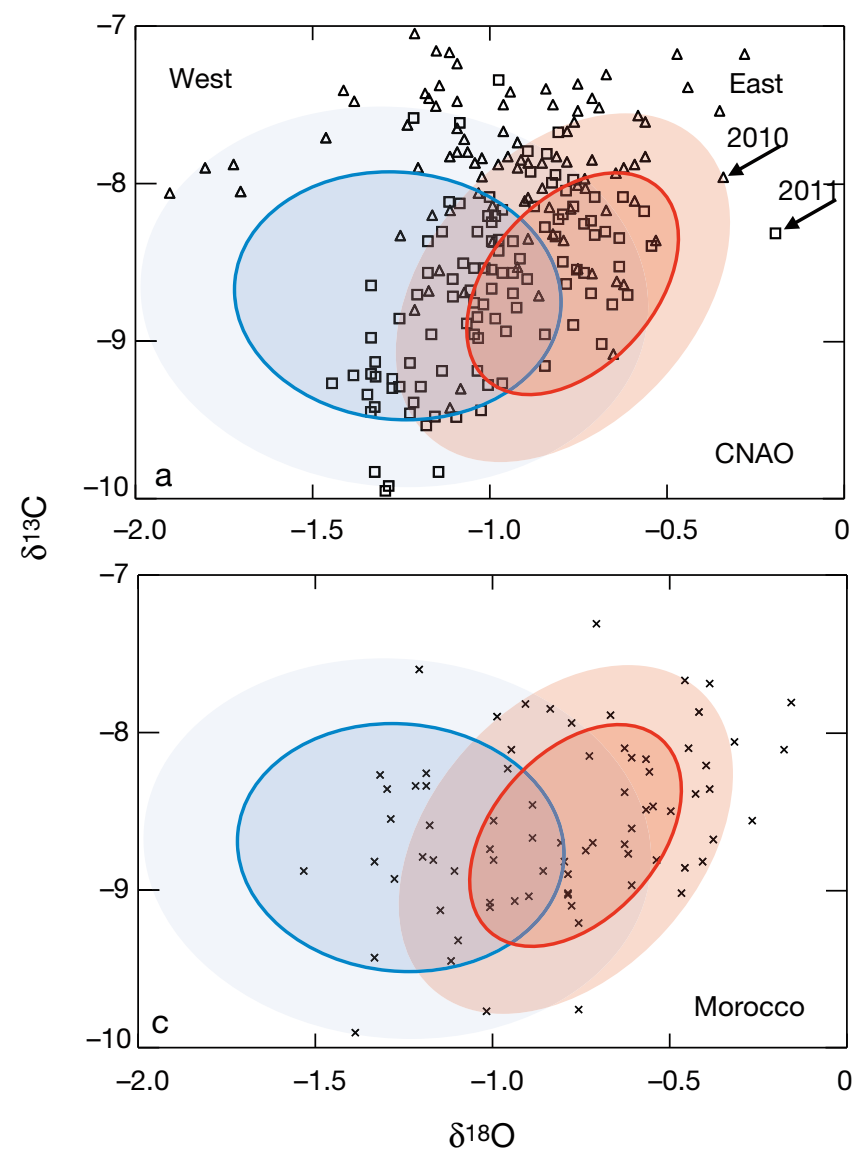

tuna, and $99 \%$ of individuals in our sample were from years included in the baseline sample. Direct MLE from HISEA for samples analyzed indicated that significant mixing of eastern and western bluefin tuna occurred in the CNAO (Fig. 3). Predicted contribution (based on MLE, $\% \pm 1 \mathrm{SD}$ ) of bluefin tuna from the smaller western population to the CNAO fishery was $20.5 \pm 6.5 \%$ based on our 2010 and 2011 sample, with the majority of bluefin tuna in this region being of eastern origin (Table 2). The presence of emigrants on both sides of the management boundary in the CNAO was detected in our sample using MLE; $44.0 \pm 16.8 \%$ of bluefin tuna collected west of $45^{\circ} \mathrm{W}$ in 2010 and 2011 were classified as eastern expatriates, while $15.1 \pm 4.9 \%$ of bluefin tuna collected east of $45^{\circ} \mathrm{W}$ were classified as western expatriates, indicating that both eastern and western migrants readily 'cross the line' and enter the other management zone. This was confirmed
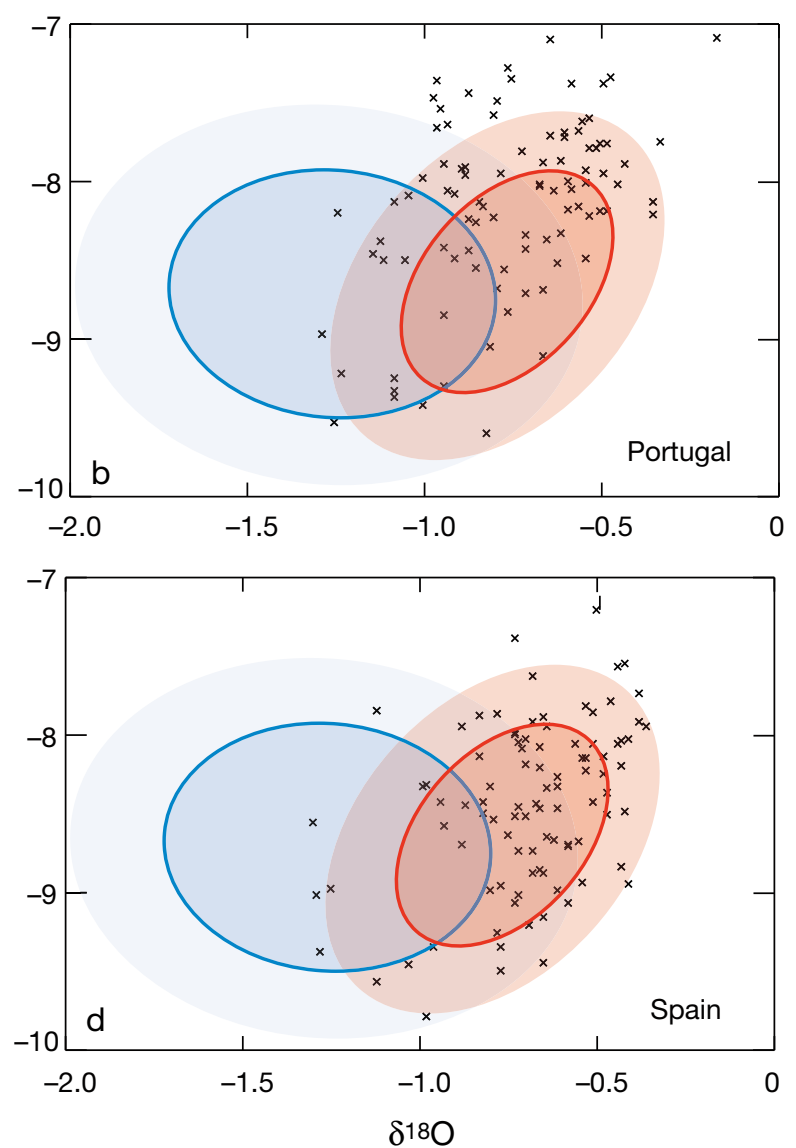

Fig. 3. Confidence ellipses (1+2 SD of sample) for otolith $\delta^{13} \mathrm{C}$ and $\delta^{18} \mathrm{O}$ (Vienne PeeDee Belemnite, VPDB) values of yearling bluefin tuna from the east (red) and west (blue) along with values of otolith cores from medium and large bluefin tuna of unknown origin collected in (a) the Central North Atlantic Ocean (CNAO) and 3 regions of the Northeast Atlantic Ocean near or within the entrance (Strait of Gibraltar) to the Mediterranean Sea: (b) Portugal, (c) Morocco, and (d) Spain. Note: bluefin tuna collected in $2010(\Delta)$ and $2011(\square)$ denoted for (a). Confidence ellipses provided for eastern and western baseline samples; inner ellipse with solid line represents $1 \mathrm{SD}$ (68\% of sample); outer ellipse with lighter shading represents 2 SD (95\% of sample) 
Table 1. Summary data for bluefin tuna (medium: 25 to $100 \mathrm{~kg}$, large: $>100 \mathrm{~kg}$ ) collected from different regions in the North Atlantic Ocean and Mediterranean Sea. Mean weight and mean fork length $( \pm 1 \mathrm{SD})$ in each region and year provided. Direct age determination from otoliths determined for subsample of adult bluefin sample ( $\mathrm{n}=163$; Rodríguez-Marín et al. 2013). Age-length key then used to estimate age of remaining bluefin tuna. Note: $99 \%$ of adult bluefin tuna had birth years within the baseline period. Gear types used to collect bluefin tuna: BB: baitboat, LL: longline, PS: purse seine, TR: trap

\begin{tabular}{|c|c|c|c|c|c|c|}
\hline Region & Year & Gear & $\mathrm{N}$ & $\begin{array}{l}\text { Weight } \\
(\mathrm{kg})\end{array}$ & $\begin{array}{l}\text { Fork length } \\
\text { (cm) }\end{array}$ & $\begin{array}{l}\text { Median age } \\
\text { (yr) (range) }\end{array}$ \\
\hline \multicolumn{7}{|c|}{ Central North Atlantic } \\
\hline \multirow[t]{2}{*}{ All } & 2010 & LL & 108 & $123.8(29.3)$ & $184.8(13.1)$ & $8(4-11)$ \\
\hline & 2011 & LL & 94 & $121.6(63.8)$ & $188.2(32.6)$ & $9(5-13)$ \\
\hline \multirow[t]{2}{*}{ East of $45^{\circ} \mathrm{W}$} & 2010 & $\mathrm{LL}$ & 106 & $123.2(29.0)$ & $184.6(12.9)$ & $8(7-11)$ \\
\hline & 2011 & LL & 71 & $98.8(31.6)$ & $180.2(19.0)$ & $8(6-13)$ \\
\hline \multirow[t]{2}{*}{ West of $45^{\circ} \mathrm{W}$} & 2010 & $\mathrm{LL}$ & 2 & $156.0(40.2)$ & $198.0(25.5)$ & $(8-10)$ \\
\hline & 2011 & LL & 23 & $164.0(85.1)$ & $203.2(45.7)$ & $11(4-13)$ \\
\hline \multicolumn{7}{|c|}{ Northeast Atlantic } \\
\hline \multirow[t]{2}{*}{ Morocco } & 2011 & TR, LL & 32 & $210.8(37.2)$ & $230.6(13.8)$ & $11(10-13)$ \\
\hline & 2012 & TR, LL & 49 & $118.9(21.1)$ & $209.0(13.7)$ & $10(7-12)$ \\
\hline Portugal & 2011 & TR & 93 & $168.4(55.9)$ & $212.3(19.4)$ & $10(8-14)$ \\
\hline \multicolumn{7}{|c|}{ Strait of Gibraltar } \\
\hline \multirow[t]{2}{*}{ Spain } & 2010 & $\mathrm{BB}, \mathrm{TR}, \mathrm{LL}$ & 16 & $156.8(41.9)$ & $229.6(21.4)$ & $11(9-14)$ \\
\hline & 2011 & $\mathrm{BB}, \mathrm{TR}, \mathrm{LL}$ & 81 & $166.0(38.6)$ & $208.0(17.7)$ & $10(7-13)$ \\
\hline \multicolumn{7}{|c|}{ Mediterranean Sea } \\
\hline Balearic Islands & 2011 & PS & 13 & $141.9(81.5)$ & $217.3(39.4)$ & $10(7-16)$ \\
\hline Sardinia & 2011 & TR & 20 & $97.2(59.8)$ & $181.5(43.3)$ & $8(4-10)$ \\
\hline Malta & 2011 & LL & 82 & $167.1(72.5)$ & $199.6(37.1)$ & $10(4-13)$ \\
\hline Cyprus & 2011 & PS & 48 & $135.5(65.8)$ & $238.0(21.1)$ & $10(7-14)$ \\
\hline
\end{tabular}

Table 2. Predicted origin of medium and large bluefin tuna collected from different regions of the Atlantic Ocean and Mediterranean Sea based on a maximum likelihood estimator (MLE) and maximum classification likelihood estimator (MCL). Estimates are given as percentages, and the mixed-stock analysis (HISEA program) was run under bootstrap mode with 500 runs to predict the error $( \pm 1 \mathrm{SD})$ around estimated percentages

\begin{tabular}{|c|c|c|c|c|c|c|c|}
\hline \multirow{2}{*}{ Region } & \multirow{2}{*}{$\mathrm{N}$} & \multicolumn{3}{|c|}{ - MLE } & \multirow{2}{*}{ \% East } & - MCL - & \multirow[b]{2}{*}{ \% Error } \\
\hline & & $\%$ East & $\%$ West & $\%$ Error & & $\%$ West & \\
\hline \multicolumn{8}{|c|}{ Central North Atlantic Ocean } \\
\hline $2010+2011$ & 202 & 79.5 & 20.5 & 6.5 & 62.7 & 37.3 & 6.9 \\
\hline 2010 & 108 & 63.9 & 36.1 & 9.6 & 47.7 & 52.3 & 9.0 \\
\hline 2011 & 94 & 90.7 & 9.3 & 5.3 & 78.3 & 21.7 & 9.7 \\
\hline \multicolumn{8}{|l|}{ West of $45^{\circ} \mathrm{W}$} \\
\hline $2010+2011$ & 25 & 44.0 & 56.0 & 16.8 & 22.5 & 77.5 & 17.0 \\
\hline \multicolumn{8}{|l|}{ East of $45^{\circ} \mathrm{W}$} \\
\hline $2010+2011$ & 177 & 84.9 & 15.1 & 4.9 & 67.4 & 32.6 & 6.0 \\
\hline 2010 & 106 & 60.9 & 39.1 & 8.5 & 46.1 & 53.9 & 8.4 \\
\hline 2011 & 71 & 98.1 & 1.9 & 2.0 & 95.3 & 4.7 & 5.5 \\
\hline \multicolumn{8}{|c|}{ Northeast Atlantic Ocean } \\
\hline Morocco & 81 & 93.9 & 6.1 & 4.7 & 77.4 & 22.6 & 7.0 \\
\hline Portugal & 93 & 100.0 & 0.0 & 0.0 & 97.5 & 2.5 & 3.7 \\
\hline \multicolumn{8}{|c|}{ Strait of Gibraltar } \\
\hline Spain & 97 & 100.0 & 0.0 & 0.0 & 99.6 & 0.4 & 1.4 \\
\hline \multicolumn{8}{|c|}{ Mediterranean Sea } \\
\hline Balearic Islands & 9 & 100.0 & 0.0 & 0.0 & 100.0 & 0.0 & 0.0 \\
\hline Sardinia & 20 & 100.0 & 0.0 & 0.0 & 100.0 & 0.0 & 0.0 \\
\hline Malta & 82 & 100.0 & 0.0 & 0.0 & 100.0 & 0.0 & 0.0 \\
\hline Cyprus & 48 & 99.1 & 0.9 & 2.9 & 84.0 & 16.0 & 9.6 \\
\hline
\end{tabular}


using the alternative classification-based estimator, with proportions from MCL often varying by at least $10 \%$ from estimates generated with the maximum likelihood approach (Table 2). Interannual variability in the overall composition of bluefin tuna in the sample from the CNAO was detected with a higher western contribution in $2010(36.1 \pm 9.6 \%)$ than in 2011 $(9.3 \pm 5.3 \%)$. Similarly, for collection east of $45^{\circ} \mathrm{W}$ (i.e. eastern management zone), the proportion of western bluefin tuna was markedly higher in 2010 $(39.1 \pm 8.5 \%)$ compared to $2011(1.9 \pm 2.0 \%)$, indicating that emigration rates and stock mixing may vary considerably from year to year in the CNAO.

The degree of stock mixing in regions of the NEAO proximal to the eastern spawning ground was also evaluated using otolith $\delta^{13} \mathrm{C}$ and $\delta^{18} \mathrm{O}$ (Fig. 3), and the presence of western migrants was limited or nil in samples from the 3 regions examined based on the maximum likelihood approach (Table 2). Bluefin tuna collected in Portuguese traps located west of the Strait of Gibraltar in the NEAO were highly similar to the eastern baseline sample, and no western migrants were detected. Similarly, adult bluefin tuna collected in Spanish traps near or within the Strait of Gibraltar were entirely of eastern origin based on MLE $(100.0 \pm 0.0 \%)$, and similar results were observed with the classification-based approach (Table 2). In contrast, western migrants were detected in our sample from the northwest coast of Africa off Morocco, and the estimated proportion of western bluefin tuna from the Moroccan trap fishery was $6.1 \pm 4.7 \%$. The contribution of western migrants in Morocco was more pronounced using the classification-based estimation, increasing from $6.1 \%$ to $22.6 \pm$ $7.0 \%$ (Table 2). Results of both MLE and MCL suggest that trans-Atlantic movement (west to east) of bluefin tuna occurs, with western migrants inhabiting waters proximal to the eastern spawning area.

High rates of population mixing in the CNAO coupled with the presence of western migrants in areas of the NEAO near the entrance of the Mediterranean Sea (i.e. Morocco) are 2 conditions that may lead to straying into the eastern spawning area. However, $\delta^{13} \mathrm{C}$ and $\delta^{18} \mathrm{O}$ values in the otolith cores of adult bluefin tuna collected from marginal seas within the Mediterranean were highly similar to the eastern baseline. The proportion of western bluefin tuna from different regions within the Mediterranean Sea from MLE was nil (Balearic Islands, Malta, and Sardinia) or negligible (Cyprus) (Fig. 4, Table 2). Estimated proportion of eastern fish was $100.0 \pm$ $0.0 \%$ for samples from the Balearic Islands (Balearic Sea), Sardinia (Tyrrhenian Sea), and Malta (Ionian
Sea); Cyprus (Levantine Sea) samples were slightly lower at $99.1 \pm 2.9 \%$. The complete lack of western migrants in samples from the Balearic Islands, Malta, and Sardinia was also predicted using the alternative classification-based estimator, but the presence of western migrants in Cyprus increased from $0.9 \%$ to $16.0 \pm 9.6 \%$ using this approach (Table 2).

\section{DISCUSSION}

The use of otolith $\delta^{13} \mathrm{C}$ and $\delta^{18} \mathrm{O}$ to determine the natal origin or environmental history of pelagic fishes, including tunas, is well established (Rooker et al. 2008a, Wells et al. 2012). Both of the markers used in the present study are particularly suitable for investigating the origin and movement of highly migratory fishes because latitudinal and longitudinal differences in seawater $\delta^{13} \mathrm{C}$ and $\delta^{18} \mathrm{O}$ occur (Elsdon et al. 2008). Here, we demonstrated that otolith $\delta^{18} \mathrm{O}$ values for yearling bluefin tuna Thunnus thynnus from the cooler and more saline waters of the eastern nursery (Mediterranean Sea and Bay of Biscay) were significantly higher relative to individuals from the western nursery (Gulf of Mexico and USA Atlantic Ocean), and similar to previously reported reference samples, this marker was useful for discriminating yearling bluefin tuna from eastern and western nurseries. Differences in otolith $\delta^{18} \mathrm{O}$ values between nurseries followed an expected geographic trend in seawater $\delta^{18} \mathrm{O}$ (LeGrande \& Schmidt 2006), which supports earlier observations that otolith $\delta^{18} \mathrm{O}$ is closely tied to seawater $\delta^{18} \mathrm{O}$ and independent of metabolic effects (Høie et al. 2003). We also determined that the difference in otolith $\delta^{13} \mathrm{C}$ values of yearling bluefin tuna from eastern and western nurseries was significant but relatively small, contributing little to population discrimination. These findings are consistent with previously documented patterns of otolith $\delta^{13} \mathrm{C}$ and $\delta^{18} \mathrm{O}$ for yearling bluefin tuna (Rooker et al. 2008a), and values reported in the Supplement build on earlier published reference data and represent a new baseline that can be used by other researchers in the future to predict the origin of Atlantic bluefin tuna.

By contrasting otolith $\delta^{13} \mathrm{C}$ and $\delta^{18} \mathrm{O}$ values of yearlings (baseline) to milled cores of adult bluefin tuna, we determined that the CNAO represents an important mixing zone for eastern and western populations. The presence of eastern and western bluefin tuna on both sides of the $45^{\circ} \mathrm{W}$ management boundary in the CNAO indicates that both populations frequently 'cross the line' at $45^{\circ} \mathrm{W}$ and enter the other 

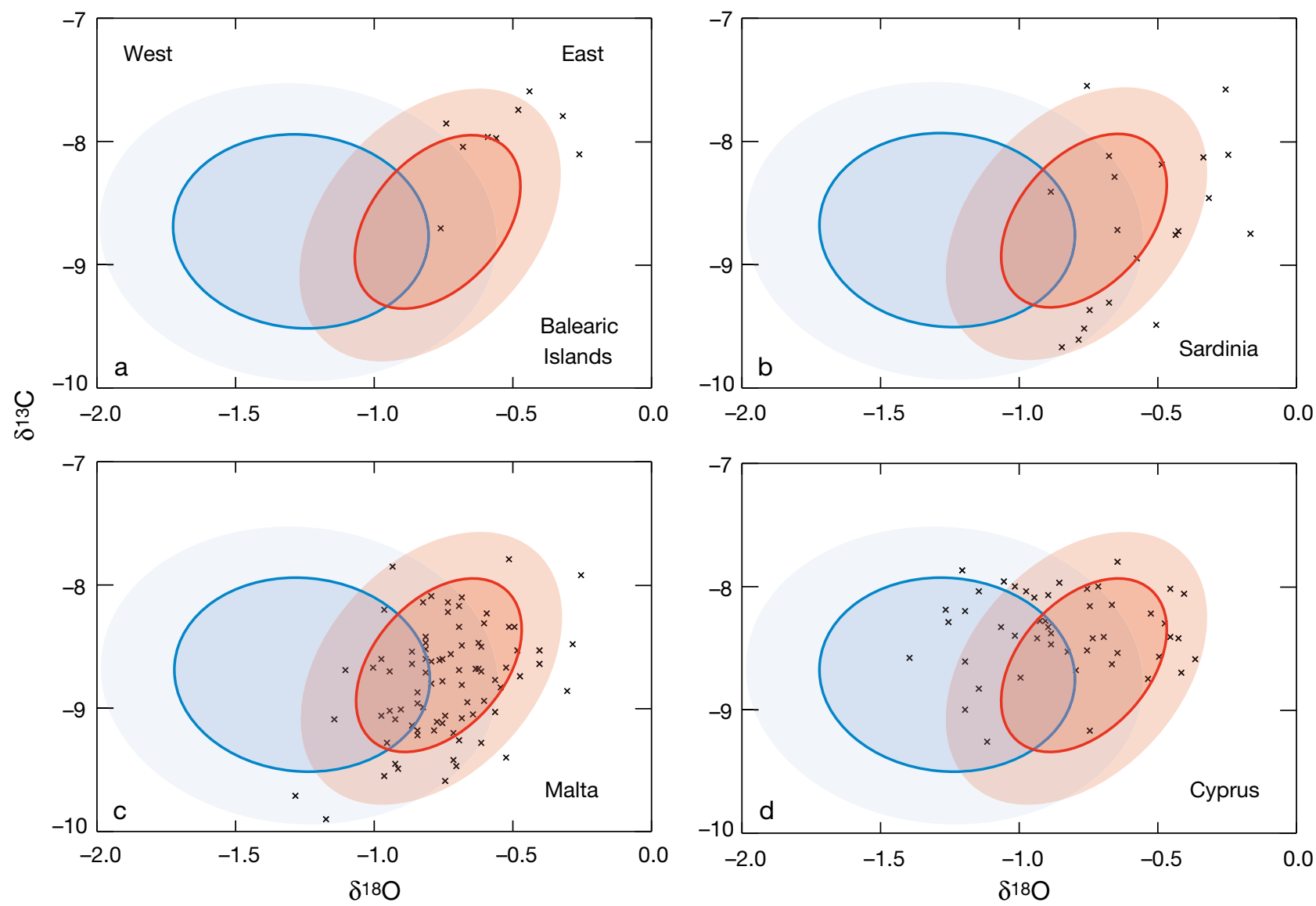

Fig. 4. Confidence ellipses $\left(1+2 \mathrm{SD}\right.$ of sample) for otolith $\delta^{13} \mathrm{C}$ and $\delta^{18} \mathrm{O}$ (Vienna PeeDee Belemnite, VPDB) values of yearling bluefin tuna from the east (red) and west (blue) along with values of otolith cores from medium and large bluefin tuna of unknown origin collected from the (a) western (Balearic Islands), (b) central (Sardinia), (c) central (Malta), and (d) eastern (Cyprus) Mediterranean Sea. Confidence ellipses provided for eastern and western baseline samples; inner ellipse with solid line represents $1 \mathrm{SD}$ ( $68 \%$ of sample); outer ellipse with lighter shading represents $2 \mathrm{SD}$ (95\% of sample)

management zone. The overall percentage of contribution of western migrants in the CNAO was less than their eastern counterparts for the samples analyzed; however, MLEs can be biased if certain stocks are rare (low contribution) or when the covariance matrix assumption is not met (Millar 1990, Ruzzante et al. 2000), and this may have led to inflated estimates for samples comprised largely of eastern migrants or, in turn, underestimated the proportion of western migrants in such samples. The MCL used indicated that the presence of western migrants near or within certain regions of the Mediterranean Sea (Morocco, Cyprus, and Portugal) is potentially higher than observed proportions based on the MLE approach (Table 2). It is also important to note that the spawning stock biomass for the eastern population is approximately an order of magnitude higher than that of the western population (ABTSRT 2011). Therefore, the presence of modest numbers of western migrants east of $45^{\circ} \mathrm{W}$ in our sample from the
CNAO (25\%) may signify that a meaningful fraction of the western population enters the eastern management zone in certain years. It is also important to note that emigration rates and stock mixing varied considerably between the years sampled, with western contribution to the eastern management zone being considerably higher in 2010 (39\%) than in $2011(2 \%)$. While the reason for interannual variability is unresolved and may be due to a variety of factors, possibly including the presence of the strong 2003 year class of western origin in our 2010 collection (Suzuki et al. 2013), such results suggest that additional sampling of bluefin tuna in the CNAO is needed to fully understand the temporal dynamics of stock mixing in this region.

The presence of western bluefin tuna was also detected in samples from the NEAO near the Strait of Gibraltar, but only in one of the regions investigated. In the Moroccan trap fishery off the African coast (south of the Strait of Gibraltar), western expatriates 
were detected in our sample, and similar to findings for the eastern population (Rooker et al. 2008a), members of the western population display transAtlantic movement. Estimated contribution of western bluefin tuna in the sample from this fishery was relatively small at $\sim 6 \%$ using the MLE approach ( $>20 \%$ with MCL) and possibly insignificant given the fact that the standard deviation around the MLE was $5 \%$. However, adult bluefin tuna tagged off Morocco have shown unexpected patterns of movement in the past, with individuals failing to return to the Mediterranean Sea during their presumed spawning period (Quilez-Badia et al. 2012). Therefore, it is possible that bluefin tuna remaining in the NEAO during the presumed spawning season were not of eastern origin but rather western migrants, although this could also be a function of skip spawning by bluefin tuna (Secor 2007). If future research confirms the presence of western migrants in this fishery at similar levels, rates of trans-Atlantic movement (W to E) by western migrants may rival rates predicted for the eastern population once estimates are adjusted for differences in population size. In contrast, western migrants were not detected in the other 2 regions assessed in the NEAO proximal to the Strait of Gibraltar. All bluefin tuna examined from the Portuguese trap fishery in the NEAO were predicted to be of eastern origin even though this fishery is located within several hundred kilometers of the Moroccan traps. The presence of a homogenous sample of eastern fish was also observed in Spanish traps located in or near the entrance to the Mediterranean Sea, suggesting that spawning adults of eastern origin likely move through waters north of the Strait of Gibraltar (i.e. Bay of Cadiz) during their return migration to the Mediterranean Sea to spawn.

Previous research has shown that a significant fraction of the eastern population emigrates from the Mediterranean Sea, with many individuals crossing the $45^{\circ} \mathrm{W}$ management boundary and entering USA waters (Rooker et al. 2008a,b). In response, our finding of eastern-origin bluefin tuna returning through the Strait of Gibraltar to spawn in the Mediterranean Sea suggests that homing to natal sites is well developed. Despite the fact that both eastern and western bluefin tuna emigrate from spawning grounds and commonly show trans-Atlantic movement, leading to stock mixing in several parts of the NAO, individuals effectively locate their natal sites to spawn. Other marine vertebrates known to display homing or natal philopatry include sharks (Feldheim et al. 2002), sea turtles (Lohmann et al. 2008), and cod (Svedang et al. 2007), and this behavior may lead to genetic structur- ing of populations. Under the assumption of natal homing, we expect that female-mediated gene flow between eastern and western populations of bluefin tuna would be limited, resulting in genetically distinct populations. Longitudinal patterns of genetic structuring (west to east) have been reported recently for bluefin tuna, and individuals from eastern (Mediterranean Sea) and western (Gulf of Mexico) spawning grounds are genetically distinct based on analysis of mtDNA control region sequence data $\left(\Phi_{\mathrm{st}}\right)$ (Boustany et al. 2008), microsatellites (Carlsson et al. 2007), and single nucleotide polymorphisms (Albaina et al. 2013). In response, the natal homing scenario proposed here for bluefin tuna based on $\delta^{13} \mathrm{C}$ and $\delta^{18} \mathrm{O}$ values in otoliths corroborates eastern and western differences detected with genetic markers.

Based on the application of otolith $\delta^{13} \mathrm{C}$ and $\delta^{18} \mathrm{O}$, we show that similar to recent findings in the NWAO (Rooker et al. 2008b), the CNAO and possibly certain regions in the NEAO represent important mixing zones of bluefin tuna populations. Recent simulation models that incorporate life history and movement patterns of eastern and western populations demonstrated that yields and rebuilding goals are highly sensitive to movement, particularly across management boundaries or zones in the Atlantic Ocean (Taylor et al. 2011, Kerr et al. 2012). Therefore, identifying the level to which eastern or western migrants 'cross the line' is critically needed to improve the quality of stock assessments. It is important to recognize that the uncertainty associated with using otolith $\delta^{13} \mathrm{C}$ and $\delta^{18} \mathrm{O}$ to predict the nursery origin of bluefin tuna is not trivial, particularly in mixing areas. Therefore, incorporating error estimates around resultant MLE (or MCL) is critical and required to properly evaluate the importance of mixing on harvest and rebuilding plans, at least until other stock identification approaches (e.g. genetics) can be combined with otolith $\delta^{13} \mathrm{C}$ and $\delta^{18} \mathrm{O}$ data to fully assess the degree of uncertainty in mixed-stock projections (Smith \& Campana 2010). Also, given that the ratio of population mixing observed here varied substantially by location and year, unraveling the secrets of bluefin tuna movement will ultimately require comprehensive and long-term sampling of individuals from all presumed mixing zones.

Acknowledgements. This work was carried out under the provision of the ICCAT Atlantic Wide Research Program for Bluefin Tuna (GBYP), funded by the European Community (Grant SI2/542789), Canada, Croatia, Japan, Norway, Turkey, United States (NMFS NA11NMF4720107), Chinese Taipei, and the ICCAT Secretariat. The contents of the paper do not necessarily reflect the point of view of ICCAT 
or of the other funders. This work was also supported by grant CTM2011-27505 by the Spanish Ministry of Economy and Competitiveness (MINECO).

\section{LITERATURE CITED}

Albaina A, Iriondo M, Fernandez IV, Laconcha U and others (2013) SNP discovery in albacore and Atlantic bluefin tuna provides insights into world-wide population structure. Anim Genet 44:678-692

Atlantic Bluefin Tuna Status Review Team (ABTSRT) (2011) Status review report of Atlantic bluefin tuna (Thunnus thynnus). National Marine Fisheries Service, Northeast Regional Office. March 22, 2011

Block BA, Teo SLH, Walli A, Boustany A and others (2005) Electronic tagging and population structure of Atlantic bluefin tuna. Nature 434:1121-1127

Boustany AM, Reeb CA, Block BA (2008) Mitochondrial DNA and electronic tracking reveal population structure of Atlantic bluefin tuna (Thunnus thynnus). Mar Biol 156: $13-24$

> Carlsson J, McDowell JR, Carlsson JE, Graves JE (2007) Genetic identity of YOY bluefin tuna from the eastern and western Atlantic spawning areas. J Hered 98:23-28

Chittaro PM, Finley RJ, Levin PS (2009) Spatial and temporal patterns in the contribution of fish from their nursery habitats. Oecologia 160:49-61

De Metrio G, Arnold GP, de la Serna JM, Megalofonou P and others (2005) Movements and migrations of north Atlantic bluefin tuna tagged with pop-up satellite tags. In: Aquatic telemetry: advances and applications. Spedicato MT, Lembo G, Marmulla G (eds) Proc the 5th Conf Fish Telemetry, Ustica, Italy, 9-13 June 2003. FAO/ COISPA, Rome

> Dickhut RM, Deshpande AD, Cincinelli A, Cochran MA and others (2009) Atlantic bluefin tuna (Thunnus thynnus) population dynamics delineated by organochlorine tracers. Environ Sci Technol 43:8522-8527

Elsdon TS, Wells BK, Campana SE, Gillanders BM and others (2008) Otolith chemistry to describe movements and life-history parameters of fishes: hypotheses, assumptions, limitations and inferences. Oceanogr Mar Biol Annu Rev 46:297-330

Fang KT (2004) Elliptically contoured distributions. In: Kotz S, Johnson NL, Read CB, Balakrishnan N, Vidakovic B (eds) Encyclopedia of statistical sciences, 2nd edn. John Wiley \& Sons, New York, NY

Feldheim KA, Gruber SH, Ashley MV (2002) The breeding biology of lemon sharks at a tropical nursery lagoon. Proc Biol Sci 269:1655-1661

Fromentin JM, Powers JE (2005) Atlantic bluefin tuna: population dynamics, ecology, fisheries and management. Fish Fish 6:281-306

Galuardi B, Royer F, Golet W, Logan J, Neilson J, Lutcavage M (2010) Complex migration routes of Atlantic bluefin tuna question current population structure paradigm. Can J Fish Aquat Sci 67:966-976

Goethel DR, Quinn TJ, Cadrin SX (2011) Incorporating spatial structure in stock assessment: movement modeling in marine fish population dynamics. Rev Fish Sci 19: 119-136

Høie H, Folkvord A, Otterlei E (2003) Effect of somatic and otolith growth on stable isotopic composition of early juvenile cod (Gadus morhua L) otoliths. J Exp Mar Biol
Ecol 289:41-58

Kerr LA, Cadrin SX, Secor DH (2012) Evaluating population effects and management implications of mixing between eastern and western Atlantic bluefin tuna stocks. ICES CM 2012/N:13

LeGrande AN, Schmidt GA (2006) Global gridded data set of the oxygen isotopic composition in seawater. Geophys Res Lett 33:L12604, doi:10.1029/2006GL026011

Lohmann KJ, Putman NF, Lohmann CMF (2008) Geomagnetic imprinting: a unifying hypothesis of long-distance natal homing in salmon and sea turtles. Proc Natl Acad Sci USA 105:19096-19101

MacKenzie BR, Mariani P (2012) Spawning of bluefin tuna in the Black Sea: historical evidence, environmental constraints and population plasticity. PLoS ONE 7:e39998

McGarigal K, Cushman S, Stafford S (2000) Multivariate statistics for wildlife and ecology research. Springer-Verlag, New York, NY

Millar RB (1987) Maximum likelihood estimation of mixedstock fishery composition. Can J Fish Aquat Sci 44: 583-590

- Millar RB (1990) Comparison of methods for estimating mixed stock fishery composition. Can J Fish Aquat Sci 47:2235-2241

Pierre C (1999) The oxygen and carbon isotope distribution in the Mediterranean water masses. Mar Geol 153:41-55

Quilez-Badia G, Cermeno P, Tudela S, Trapaga SS, Graupera E (2012) Spatial movements of bluefin tuna revealed by electronic tagging in the Mediterranean Sea and in Atlantic waters of Morocco. ICCAT SCRS/2012/123

Rodríguez-Marín E, Rodríguez-Cabello C, De la Serna JM, Cort JL and others (2005) A review of bluefin tuna juveniles tagging information and mortality estimation in waters around the Iberian Peninsula. ICCAT Col Vol Sci Pap 58:1388-1402

Rodríguez-Marín E, Luque P, Quelle P, Ruiz M, Perez B (2013) Age determination analyses of Atlantic bluefin tuna (Thunnus thynnus) within the Biological and Genetic Sampling and Analysis Contract (GBYP). SCRS/ 2013/080

Rooker JR, Secor DH, De Metrio G, Rodríquez-Marín E, Fenech Farrugia A (2006) Evaluation of population structure and mixing rates of Atlantic bluefin tuna from chemical signatures in otoliths. Collect Vol Sci Pap ICCAT 59:813-818

Rooker JR, Alvarado Bremer JR, Block BA, Dewar H and others (2007) Life history and stock structure of Atlantic bluefin tuna (Thunnus thyunnus). Rev Fish Sci 15: 265-310

Rooker JR, Secor DH, DeMetrio G, Schloesser R, Block BA, Neilson JD (2008a) Natal homing and connectivity in Atlantic bluefin tuna populations. Science 322: 742-744

Rooker JR, Secor DH, DeMetrio G, Kaufman JA, Belmonte Rios A, Ticina A (2008b) Evidence of trans-Atlantic mixing and natal homing of bluefin tuna from stable isotopes in otoliths. Mar Ecol Prog Ser 368:231-239

Ruzzante DE, Taggart CT, Lang S, Cook D (2000) Mixedstock analysis of Atlantic cod near the Gulf of St. Lawrence based on microsatellite DNA. Ecol Appl 10:1090-1109

Schloesser RW, Rooker JR, Louchouarn P, Neilson JD, Secor $\mathrm{DH}$ (2009) Interdecadal variation in seawater $\delta^{13} \mathrm{C}$ and $\delta^{18} \mathrm{O}$ recorded in fish otoliths. Limnol Oceanogr 54: 1665-1668 
Schloesser RW, Neilson JD, Secor DH, Rooker JR (2010) Natal origin of Atlantic bluefin tuna (Thunnus thynnus) from the Gulf of St. Lawrence based on $\delta^{13} \mathrm{C}$ and $\delta^{18} \mathrm{O}$ in otoliths. Can J Fish Aquat Sci 67:563-569

Secor DH (2002) Is Atlantic bluefin tuna a metapopulation? Collect Vol Sci Pap ICCAT 54:3390-3399

Secor DH (2007) Do some Atlantic bluefin tuna skip spawning? Collect Vol Sci Pap ICCAT 60:1141-1153

Smith SJ, Campana SE (2010) Integrated stock mixture analysis for continuous and categorical data, with application to genetic-otolith combinations. Can J Fish Aquat Sci 67:1533-1548

Suzuki Z, Kimoto A, Sakai O (2013) Note on the strong 2003

Editorial responsibility: Stylianos Somarakis,

Heraklion, Greece year-class that appeared in the Atlantic bluefin fisheries. Collect Vol Sci Pap ICCAT 69:229-234

Svedang H, Righton D, Jonsson P (2007) Migratory behavior of Atlantic cod Gadus morhua: natal homing is the prime stock-separating mechanism. Mar Ecol Prog Ser 345:1-12

Taylor NG, McAllister MK, Lawson GL, Carruthers T, Block BA (2011) Atlantic bluefin tuna: a novel multistock spatial model for assessing population biomass. PLoS ONE 6:e27693

Wells RJD, Rooker JR, Itano DG (2012) Nursery origin of yellowfin tuna in the Hawaiian Islands. Mar Ecol Prog Ser 461:187-196

Submitted: December 10, 2013; Accepted: March 6, 2014 Proofs received from author(s): April 30, 2014 